Article

\title{
Optimization of Bioelectricity Generation in Constructed Wetland-Coupled Microbial Fuel Cell Systems
}

\author{
Hailiang Song ${ }^{1, *}$, Shuai Zhang ${ }^{1}$, Xizi Long ${ }^{1}$, Xiaoli Yang ${ }^{2}$, Hua Li ${ }^{1}$ and Wenli Xiang ${ }^{1}$ \\ 1 School of Energy and Environment, Southeast University, Nanjing 210096, China; \\ zhangshuai198702@163.com (S.Z.); xizi_long@163.com (X.L.); lihua20170305@163.com (H.L.); \\ rmth@sohu.com (W.X.) \\ 2 School of Civil Engineering, Southeast University, Nanjing 210096, China; yangxiaoli@seu.edu.cn \\ * Correspondence: songhailiang@seu.edu.cn; Tel.: +86-25-8379-4171
}

Academic Editors: Ranka Junge and Fabio Masi

Received: 27 November 2016; Accepted: 3 March 2017; Published: 6 March 2017

\begin{abstract}
Constructed wetland-coupled microbial fuel cell systems (CW-MFCs) incorporate an aerobic zone and an anaerobic zone to generate electricity that achieves the oxidative degradation of contaminants. However, there are few reports on the performance of such coupled systems. In this study, we determined the optimal configuration of CW-MFCs to characterize their electricity generation performance. Based on the results using different levels of dissolved oxygen among the CW-MFCs, we concluded that a 20-cm distance between the anode and cathode produced an optimal removal of chemical oxygen demand (COD) of $94.90 \%$ with a $0.15 \mathrm{~W} / \mathrm{m}^{3}$ power density, $339.80 \Omega$ internal resistance, and $0.31 \%$ coulombic efficiency. In addition, a COD of $200 \mathrm{mg} / \mathrm{L}$ provided greater electricity generation $\left(741 \mathrm{mV}\right.$ open circuit voltage, $0.20 \mathrm{~W} / \mathrm{m}^{3}$ power density, $339.80 \Omega$ internal resistance, and $0.49 \mathrm{~mA}$ current) and purification ability ( $90.45 \%$ COD removal) to meet system COD loading limitations than did higher COD values. By adding $50 \mathrm{mM}$ phosphate buffer solution to synthetic wastewater, relatively high conductivity and buffer capacity were achieved, resulting in improvement in electricity generation. These findings highlight important aspects of bioelectricity generation in CW-MFCs.
\end{abstract}

Keywords: constructed wetland; microbial fuel cell systems; bioelectricity generation; power density; internal resistance

\section{Introduction}

Microbial fuel cells (MFCs), which make use of domestic sewage, industrial effluent, leachate, sediment, and rhizodeposits as biodegradable substrates, offer a technology for electricity generation in addition to benefits for the environment [1-3]. Organic matter can be used as a renewable resource to generate electrons and protons via electrochemically active bacteria in MFCs [4-6]. Protons are released into solution and electrons are produced at the anode; subsequently, at the interface of the cathode, electrons pass through the outer circuit before they can reach the cathode and combine with electron acceptors $[7,8]$. Single-chamber MFCs with an anion exchange membrane (AEM), which serves to thoroughly separate the aerobic and anaerobic regions, are the most widely studied MFC systems $[9,10]$.

Numerous studies have focused on exploiting constructions in MFCs [11], and there is a need to study the systems with electric potential between the anode and cathode. Various MFC systems with such configurations have been the focus of recent studies. Plant-MFCs and MFC-coupled constructed wetlands (CW-MFCs) have also been studied $[12,13]$. In one such system, microbes in the anaerobic 
anode compartment, where the roots of plants were located, were able to use the carbon dioxide fixed by photosynthesis to convert rhizodeposits (e.g., sugars, organic acids, polymeric carbohydrates, and enzymes), and achieved a maximum power density of $67 \mathrm{~mW} / \mathrm{m}^{2}$ [14]. In fact, roots can release a lot of oxygen, and the oxygen promoted the electricity generation performance of the cathode. Chiranjeevi et al. integrated an MFC with a submerged and emergent macrophyte-based system to harvest energy [15]. The roots do not provide organic carbon to the anode.

The design of the vertical subsurface-flow CW-MFC (VSFCW-MFC) is not drawn from the empirical design of conventional CWs because it needs to be suitable for electricity generation. Taking high power density as an example, the system requires low internal resistance, which is achieved by reducing the distance between the two electrodes and increasing the conductivity of the electrolyte. Previous studies have suggested that a suitable distance between the anode and cathode is $18-62 \mathrm{~cm}$. Phosphate buffer solution (PBS) in the MFC contributes to maintaining a neutral $\mathrm{pH}$ for microorganisms, increasing conductivity, and avoiding the transportation limitation of protons in the biofilm by forming the conjugate acid of the buffer [16]. A concentrated PBS is expected to improve the performance of the system. Moreover, the rate of biodegradation is limited, in particular for some complex polymeric organic substrates [17]. Polymeric organic substrate wastewater passing through the anode flushes the cathode and causes a decrease in the cathode potential, which results in a decrease in electricity production. Villasenor et al. reported that degradation efficiency decreased with increasing chemical oxygen demand (COD) and concentration, and correspondingly, the electricity produced in a horizontal subsurface flow CW-MFC decreased [18].

Most studies have focused on the effects of redox conditions [19], electrode material [20], plants and bacteria [21], and flow models of organic loading [19]. However, few studies have explored the effects of the system structure and presence of PBS on performance. Therefore, we investigated the effects of varying the distance between the electrodes, influent COD loading, and PBS to improve the electricity generation and pollutant removal of a VSFCW-MFC.

\section{Materials and Methods}

\subsection{Construction of the Fuel Cell}

The MFC was integrated with a vertical organic glass pipe (internal diameter, $30 \mathrm{~cm}$; height, $50 \mathrm{~cm}$ ) with sampling outlets every $5 \mathrm{~cm}$ along its length and was filled with sections consisting of a gravel layer (gravel diameter, 3 mm, Nanjing Zhongdong Chemical Glass Instrument Co., Ltd, Nanjing, China), the anodic electrode layer (thickness, $10 \mathrm{~cm}$ ), a second gravel layer, and the cathode layer (thickness, $2.5 \mathrm{~cm}$ ), as shown in Figure 1a. Both electrodes consisted of granular activated carbon (GAC; 3-5 mm in diameter and 500-900 $\mathrm{m}^{2} / \mathrm{g}$ in specific area, Jiangsu Zhuxi Activated Carbon Co., Ltd., Nanjing, China) pretreated according to previous methods [22]. A stainless steel mesh current collector (304SS; 30-cm total diameter, 3-mm thickness, 1.7-mm mesh size, and 0.42-mm wire diameter, Nanjing Zhongdong Chemical Glass Instrument Co., Ltd., Nanjing, China) buried in the electrode was linked to the external circuit with an insulated titanium wire; the circuit was connected to a data acquisition module to measure the voltage (V) data (DAM-3058R and DAM-3210, Art Technology Co. Ltd., Beijing, China). The total volume of the system was $35.3 \mathrm{~L}$, with a total effective working volume of $12.4 \mathrm{~L}$, compared to an effective volume of $2.1 \mathrm{~L}$ for the anode. After they had been planted for 1 month at an ambient temperature of $28^{\circ} \mathrm{C}, 10$ Phragmites australis were transplanted in the cathode layer. To culture the microorganisms, anaerobic sludge (mixed liquor suspended solids, $60 \mathrm{~g} / \mathrm{L}$ ) was collected from the East City Municipal Wastewater Treatment Plant, Nanjing, China. Condensed anaerobic slurry (GAC: Sludge volumetric ratio, 2.5:1) was added to the VSFCW-MFC, and synthetic wastewater (SW) was transported using a peristaltic pump (BT100-1L, Baoding Longer Precision Pump Co., Ltd., Baoding, China). The nutrient solution used in the start-up phase contained: Glucose, $200.00 \mathrm{mg} / \mathrm{L} ; \mathrm{KNO}_{3}, 252.50 \mathrm{mg} / \mathrm{L} ; \mathrm{K}_{2} \mathrm{HPO}_{4} \cdot 3 \mathrm{H}_{2} \mathrm{O}, 26.32 \mathrm{mg} / \mathrm{L} ; \mathrm{NaHCO}_{3}, 336.00 \mathrm{mg} / \mathrm{L}$; $\mathrm{NaCl} 330.00, \mathrm{mg} / \mathrm{L}$; and $10.00 \mathrm{~mL}$ micronutrients [1]. Based on our pre-experiment, the hydraulic 
retention time was estimated to be $48 \mathrm{~h}$, and the flow rate of the system was $6.36 \mathrm{~mL} / \mathrm{min}$ (surface loading rate: $0.0055 \mathrm{~m}^{3} /\left(\mathrm{m}^{2} \cdot \mathrm{h}\right)$ ). The VSFCW-MFCs were covered with black adhesive tape to prevent algae growth. All experiments were operated continuously for 3 months indoors at $28 \pm 2{ }^{\circ} \mathrm{C}$ with a relative humidity of $55 \%-70 \%$. The nutrient solution (first trial: SW with PBS, Table 1 ) was used during the stable period.

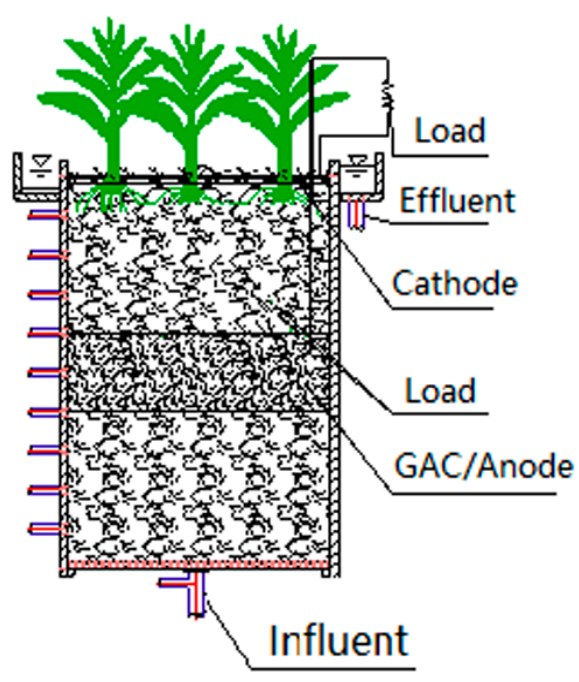

(a)

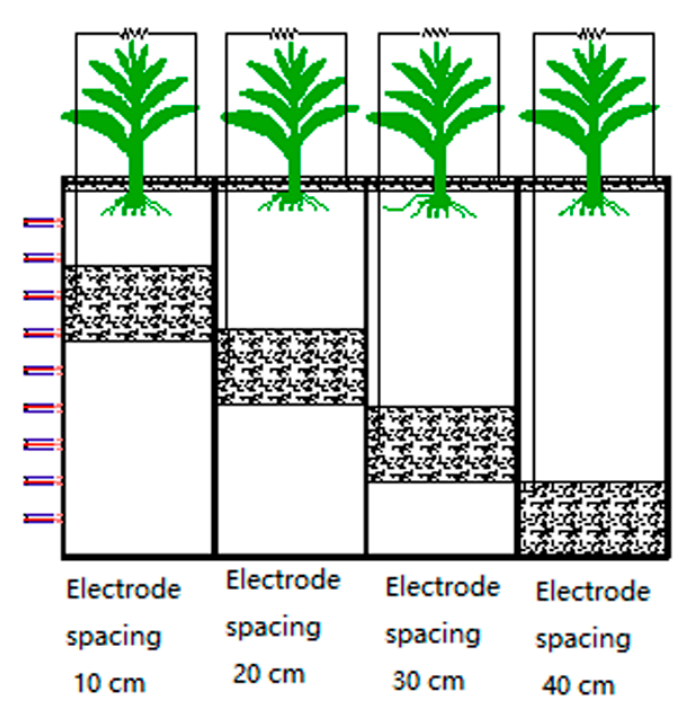

(b)

Figure 1. Schematics of the vertical subsurface-flow wetland-coupled microbial fuel cell systems (VSFCW-MFCs). (a) Experimental set-up and (b) VSFCW-MFCs with distances ranging from 10 to $40 \mathrm{~cm}$ between the electrodes.

Table 1. Concentrations and components of synthetic domestic wastewater in the VSFCW-MFCs.

\begin{tabular}{|c|c|c|c|c|c|}
\hline \multicolumn{2}{|c|}{$\begin{array}{l}\text { First Trial: Synthetic Wastewater (SW) } \\
\text { with Phosphate Buffer Solution (PBS) }\end{array}$} & \multicolumn{2}{|c|}{ Second Trial: SW without PBS } & \multicolumn{2}{|c|}{ Third Trial: SW without PBS } \\
\hline Ingredient & Concentration $(\mathrm{mg} / \mathrm{L})$ & Ingredient & Concentration $(\mathrm{mg} / \mathrm{L})$ & Ingredient & Concentration $(\mathrm{mg} / \mathrm{L})$ \\
\hline Glucose & 200.00 & Glucose & 200.00 & Glucose & 200.00 \\
\hline Carbamide & 10.00 & $\mathrm{KNO}_{3}$ & 252.50 & $\mathrm{KNO}_{3}$ & 252.50 \\
\hline $\mathrm{NH}_{4} \mathrm{Cl}$ & 310.00 & $\mathrm{KH}_{2} \mathrm{PO}_{4}$ & 26.32 & $\mathrm{KH}_{2} \mathrm{PO}_{4}$ & 26.32 \\
\hline $\mathrm{NaH}_{2} \mathrm{PO}_{4}$ & 4970.00 & $\mathrm{NaHCO}_{3}$ & 336.00 & $\mathrm{NaHCO}_{3}$ & 336.00 \\
\hline $\mathrm{Na}_{2} \mathrm{HPO}_{4}$ & 2750.00 & $\mathrm{MgSO}_{4} \cdot 7 \mathrm{H}_{2} \mathrm{O}$ & 200.00 & $\mathrm{NaCl}$ & 330.00 \\
\hline $\mathrm{KCl}$ & 130.00 & $\mathrm{CaCl}_{2}$ & 15.00 & $\mathrm{MgSO}_{4} \cdot 7 \mathrm{H}_{2} \mathrm{O}$ & 200.00 \\
\hline $\mathrm{NaHCO}_{3}$ & 3130.00 & $\mathrm{FeC}_{3} \cdot 6 \mathrm{H}_{2} \mathrm{O}$ & 1.00 & $\mathrm{CaCl}_{2}$ & 15.00 \\
\hline$\left(\mathrm{NH}_{4}\right)_{2} \mathrm{SO}_{4}$ & 560.00 & $\mathrm{MnSO}_{4} \cdot \mathrm{H}_{2} \mathrm{O}$ & 28.00 & $\mathrm{FeC}_{3} \cdot 6 \mathrm{H}_{2} \mathrm{O}$ & 1.00 \\
\hline $\mathrm{MgSO}_{4} \cdot 7 \mathrm{H}_{2} \mathrm{O}$ & 200.00 & $\mathrm{CoCl}_{2} \cdot 6 \mathrm{H}_{2} \mathrm{O}$ & 2.40 & $\mathrm{MnSO}_{4} \cdot \mathrm{H}_{2} \mathrm{O}$ & 28.00 \\
\hline $\mathrm{CaCl}_{2}$ & 15.00 & $\mathrm{Na}_{2} \mathrm{Mo}_{4} \cdot 2 \mathrm{H}_{2} \mathrm{O}$ & 0.40 & $\mathrm{CoCl}_{2} \cdot 6 \mathrm{H}_{2} \mathrm{O}$ & 2.40 \\
\hline $\mathrm{FeCl}_{3} \cdot 6 \mathrm{H}_{2} \mathrm{O}$ & 1.00 & - & - & $\mathrm{Na}_{2} \mathrm{Mo}_{4} \cdot 2 \mathrm{H}_{2} \mathrm{O}$ & 0.40 \\
\hline $\mathrm{MnSO}_{4} \cdot \mathrm{H}_{2} \mathrm{O}$ & 28.00 & - & - & - & - \\
\hline $\mathrm{CoCl}_{2} \cdot 6 \mathrm{H}_{2} \mathrm{O}$ & 2.40 & - & - & - & - \\
\hline $\mathrm{Na}_{2} \mathrm{Mo}_{4} \cdot 2 \mathrm{H}_{2} \mathrm{O}$ & 0.40 & - & - & - & - \\
\hline
\end{tabular}

\subsection{Electrochemical and Chemical Monitoring}

A variation of output voltage of approximately $10 \%$ per day indicated stabilization in the CW-MFCs. The voltage between the anode and cathode was recorded automatically every 5 min using a data acquisition module (DAM-3058R and DAM-3210, Art Technology Co. Ltd., Beijing, China). The current density was calculated following Ohm's Law based on the effective working volume $(2.1 \mathrm{~L})$ of the anode and the power density equation given below:

$$
P=I \cdot U / V
$$


where $P$ is power density, $I$ is current, $U$ is the voltage, and $V$ the effective working volume $(2.1 \mathrm{~L})$ of the anode.

$$
P t=I \cdot U / V
$$

where $P t$ is power density, $I$ is current, $U$ is the voltage, and $V$ the total effective working volume (12.4 L) of the VSFCW-MFC.

The polarization profile [23] was obtained 1 week after a period of stable operation (after 20 days of operation), during which the resistance load increased from 5 to $10^{5} \Omega$. The open circuit voltage was not measured until the system had been kept open for $12 \mathrm{~h}$.

The coulombic efficiency resulting from the redox reaction was calculated from the following equation [1]:

$$
\eta_{C E}=\frac{I}{F \times \frac{4}{32} \times Q_{i n} \times \Delta C O D}
$$

where $\eta_{C E}$ is coulombic efficiency, $F$ represents the Faraday constant, $Q_{\text {in }}$ represents the water flow of influent $(\mathrm{L} / \mathrm{s})$, and $\triangle C O D$ is the variation in effluent and influent $C O D$.

The dissolved oxygen (DO) of the wastewater from the sampling outlets was measured using a DO instrument (DO-31P; DKK-TOA, Tokyo, Japan) during the period of stable operation. The standard potential of calomel reference electrode was made by the Shanghai INESA Scientific Instrument Co., Ltd. (323-01; Shanghai, China). COD was monitored according to the American Public Health method [24]. Linear regression was used to analyze the correlation between voltage and DO concentration with Microsoft Excel 2010.

\subsection{Operating Parameters}

To determine the effects of changing the distance between the two electrodes, the anode was positioned 10, 20, 30, and $40 \mathrm{~cm}$ from the cathode in the period of stable operation (Figure 1b). The components of the SW with and without PBS are shown in Table $1[1,25,26]$.

\section{Results and Discussion}

\subsection{Effects of DO on Voltage in the VSFCW-MFC System}

The average voltages of the different distances between the two electrodes, except for the start-up stage, are shown in Figure 2a. The $20-\mathrm{cm}$ spacing had a voltage of around $560 \mathrm{mV}$ throughout the experiment, while the $30-\mathrm{cm}$ spacing yielded a voltage of $520 \mathrm{mV}$. However, the $10-\mathrm{cm}$ and $40-\mathrm{cm}$ spacings produced voltages of only about $440 \mathrm{mV}$ and $420 \mathrm{mV}$, respectively.

Organic matter in wastewater is degraded and consumed by DO, and thus forms anoxic conditions suitable for catalytic exoelectrogens. Oxygen demand in the wastewater decreased and DO was gradually replenished, entering the cathode compartment at a high concentration compared to other studies [18]. In addition, the macrophytes raised the DO concentration and simultaneously produced negligible rhizodeposits.

The variation in DO was measured at the sampling outlets along the VSFCW-MFCs (Figure 2b). When the same SW was fed into the system and electron accepters were neglected, the cathode potential was determined primarily by the DO concentration in the MFCs [27]. The anaerobic condition was related to the concentration of the exoelectrogens acting as efficient catalysts, which suggests that electricity production was closely related to the DO level. First, DO decreased to a minimum, and then increased starting about halfway along the length of the system. Comparing the four systems, the minimum DO $(0.43 \mathrm{mg} / \mathrm{L})$ occurred in the $20-\mathrm{cm}$ electrode spacing, and the maximum $(4.73 \mathrm{mg} / \mathrm{L})$ was unexpectedly observed in the cathode. The electrode spacings of 10,30 , and $40 \mathrm{~cm}$ yielded minimum DO concentrations of $0.60,0.54$, and $0.52 \mathrm{mg} / \mathrm{L}$, respectively, and maximum DO concentrations of $4.30,4.47$, and $3.75 \mathrm{mg} / \mathrm{L}$, respectively. In addition, the DO in the anode zones was $0.60-1.23 \mathrm{mg} / \mathrm{L}$, $0.77-1.135 \mathrm{mg} / \mathrm{L}$, and $0.79-1.37 \mathrm{mg} / \mathrm{L}$, respectively. The variation in DO between the anode and 
cathode of the systems with different electrode spacings was significantly (Linear regression, $r=-0.991$, $p<0.001$ ) negatively correlated with the difference in voltage (Figure 2c).

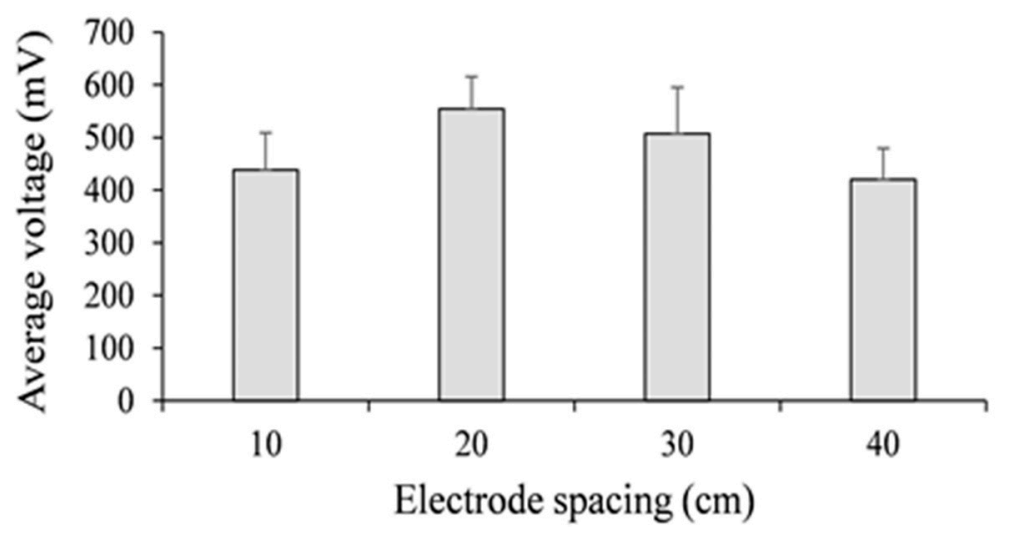

(a)

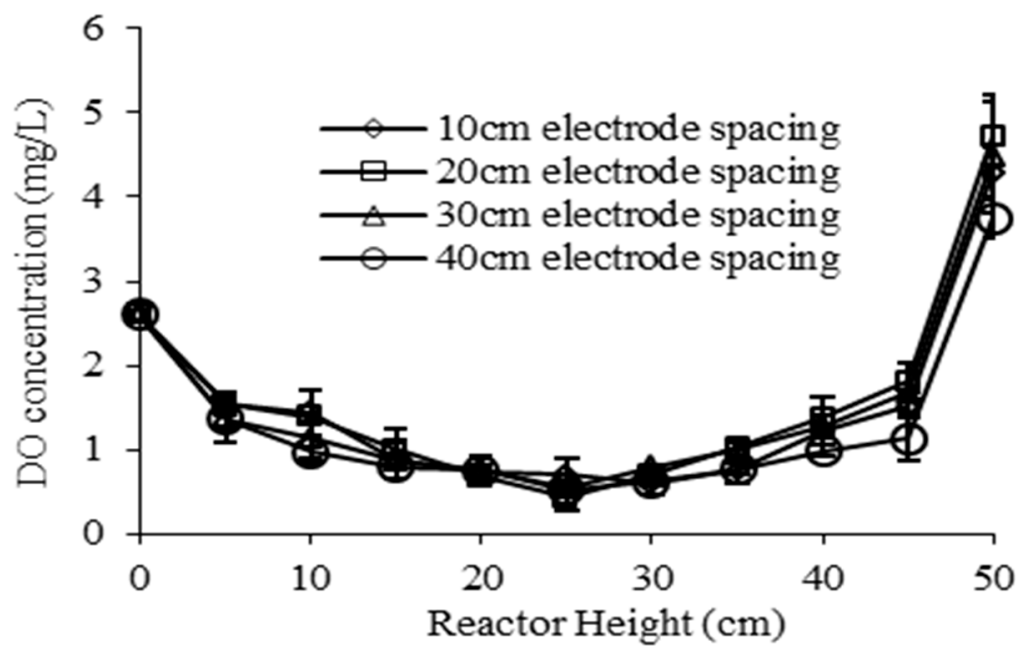

(b)

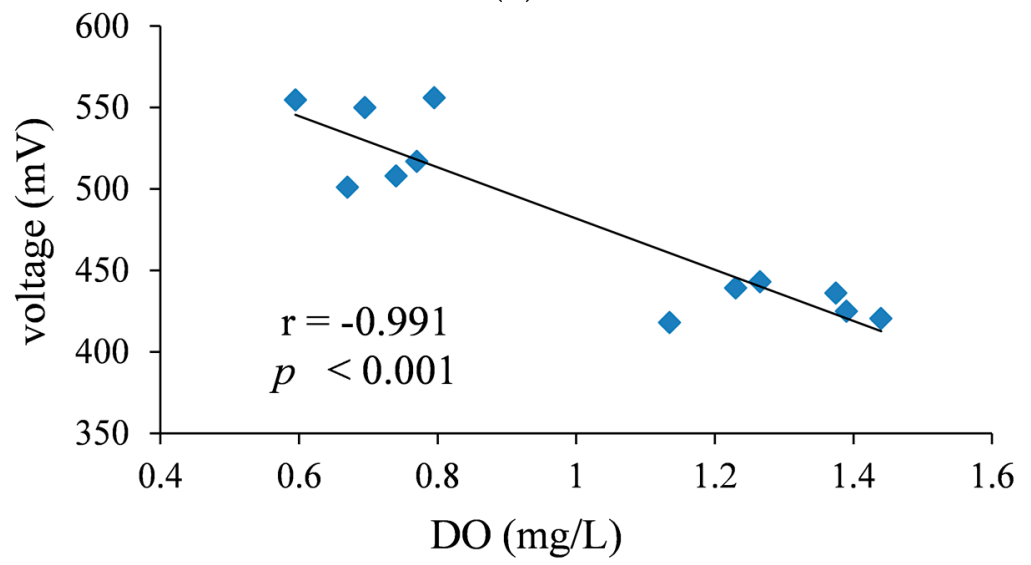

(c)

Figure 2. Effects of dissolved oxygen (DO) on voltage in VSFCW-MFCs. (a) Average voltages of different electrode spacings in the experimental system (mean $\pm \mathrm{SE}, n=4)$; (b) Variation in DO concentration from the bottom to the top of the reactors $(\mathrm{mg} / \mathrm{L})($ mean $\pm \mathrm{SE}, n=4)$; (c) Correlation of voltage with DO concentration at a single time point in the four reactors (The voltage and DO measurement was taken at three time points respectively). 


\subsection{Bioelectricity Generation with Different Electrode Spacings}

The polarization and power density profiles with different external resistances are shown in Figure 3. The maximum open circuit voltage of $741 \mathrm{mV}$ was achieved for the 20-cm spacing with a maximum current density of $0.49 \mathrm{~A} / \mathrm{m}^{3}$ and maximum power density of $0.20 \mathrm{~W} / \mathrm{m}^{3}\left(\mathrm{Pt}=0.034 \mathrm{~W} / \mathrm{m}^{3}\right)$ with an external resistance of approximately $400 \Omega$. An open circuit voltage of $717 \mathrm{mV}$ was measured in the $30-\mathrm{cm}$ spacing system, which obtained a maximum current density of $0.45 \mathrm{~A} / \mathrm{m}^{3}$ and maximum power density of $0.17 \mathrm{~W} / \mathrm{m}^{3}\left(\mathrm{Pt}=0.029 \mathrm{~W} / \mathrm{m}^{3}\right)$ with an external resistance of approximately $400 \Omega$. Lower performances were observed when the electrode spacing was $10 \mathrm{~cm}$ and $40 \mathrm{~cm}$, with a maximum open circuit voltage of 671 and $635 \mathrm{mV}$, respectively, maximum current density of $0.37 \mathrm{~A} / \mathrm{m}^{3}$ and $0.36 \mathrm{~A} / \mathrm{m}^{3}$, and maximum power density of $0.12 \mathrm{~W} / \mathrm{m}^{3}\left(\mathrm{Pt}=0.020 \mathrm{~W} / \mathrm{m}^{3}\right)$ and $0.11 \mathrm{~W} / \mathrm{m}^{3}$ $\left(\mathrm{Pt}=0.019 \mathrm{~W} / \mathrm{m}^{3}\right)$. The internal resistance (Rint) was $385.80,339.80,367.68$, and $406.32 \Omega$ for a spacing of $10,20,30$, and $40 \mathrm{~cm}$, respectively, using the linear part of the polarization curve (the external resistance varied between 100 and $1000 \Omega$ ).

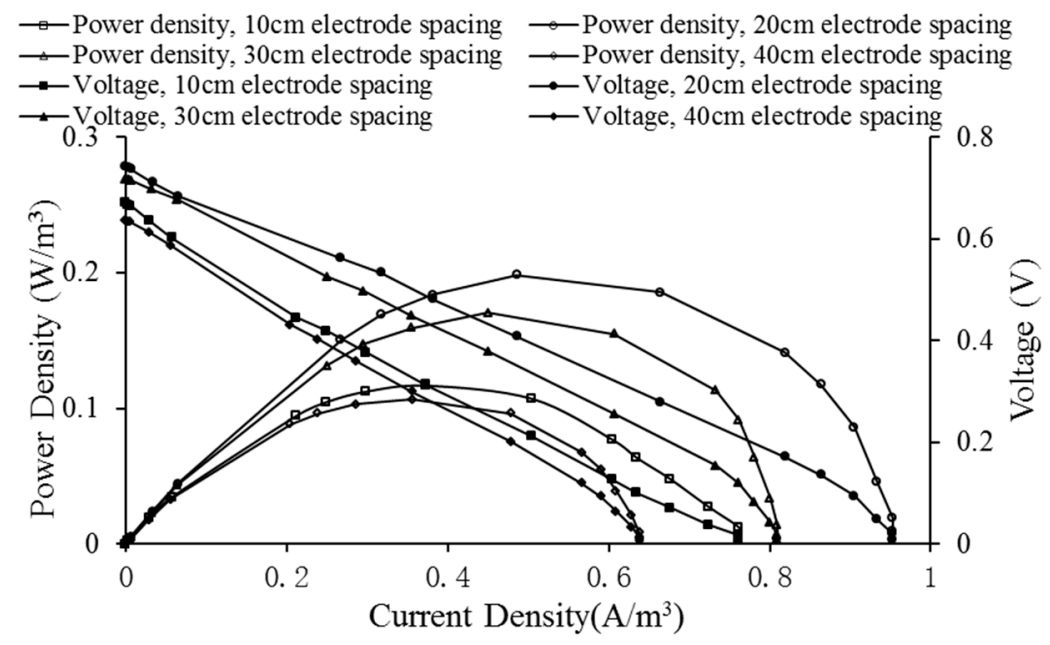

Figure 3. Polarization curves and power density-current density curves for different electrode spacings in VSFCW-MFCs.

Without distinguishing the resistance from different sources, the internal resistance consisted of the activation resistance in the electrodes, the ohmic resistance, and the diffusion resistance. Fan et al. proposed an equation to quantify the distribution of the internal resistance, and showed that the distance between the anode and cathode was inversely proportional to the power generation [28]. However, except for the 10-cm spacing system (DO present in the system also affected the resistance distribution), the resistance decreased when the spacing of the two electrodes decreased from 40 to $20 \mathrm{~cm}$. The maximum current density and minimum internal resistance were achieved simultaneously with an electrode spacing of $20 \mathrm{~cm}$. However, the resistance of the VSFCW-MFC was high, consistent with a previous report (internal resistance $188 \Omega$ ) [15]. This might be attributable to the poor contact between the GAC and the steel mesh as well as the large distance between the two electrodes, which caused a decrease in the power density compared to the $9.8 \mathrm{~W} / \mathrm{m}^{3}$ with SW $[18,29]$.

The variation in COD with different electrode spacing versus reactor height is shown in Figure 4, and the performance of the VSFCW-MFC energy output is summarized in Table 2. The reactors were operated with consecutive flow and an external resistance of $1000 \Omega$. 


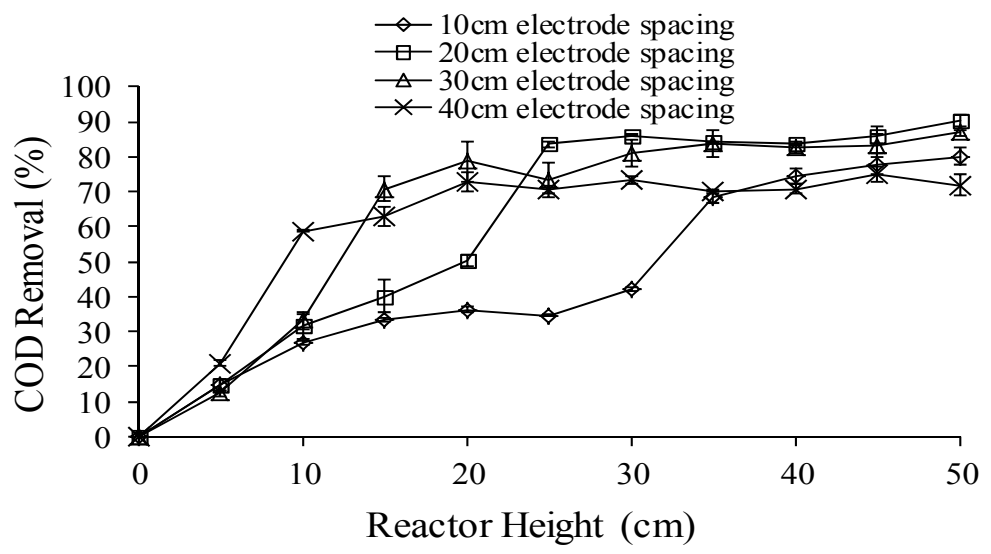

Figure 4. Chemical oxygen demand (COD) removal efficiencies of different electrode spacings in VSFCW-MFCs (mean \pm SE, $n=4$ ).

Table 2. Energy output of the VSFCW-MFCs. (mean $\pm \mathrm{SE}, n=4$ ).

\begin{tabular}{|c|c|c|c|c|}
\hline $\begin{array}{c}\text { Electrode } \\
\text { Spacing }(\mathrm{cm})\end{array}$ & $\begin{array}{c}\text { Current } \\
\text { Generation (mA) }\end{array}$ & $\begin{array}{l}\text { Power Density } \\
\quad\left(\mathrm{W} / \mathrm{m}^{3}\right)\end{array}$ & $\begin{array}{l}\text { COD Removal (\%) } \\
\text { in Effluent }\end{array}$ & $\begin{array}{c}\text { Coulombic } \\
\text { Efficiency (\%) }\end{array}$ \\
\hline 10 & $0.44 \pm 0.05$ & $0.09 \pm 0.01$ & $89.60 \pm 3.21$ & $0.26 \pm 0.03$ \\
\hline 20 & $0.56 \pm 0.06$ & $0.15 \pm 0.02$ & $94.90 \pm 2.44$ & $0.31 \pm 0.02$ \\
\hline 30 & $0.52 \pm 0.04$ & $0.13 \pm 0.02$ & $93.31 \pm 2.75$ & $0.30 \pm 0.03$ \\
\hline 40 & $0.42 \pm 0.04$ & $0.08 \pm 0.01$ & $85.42 \pm 3.54$ & $0.26 \pm 0.01$ \\
\hline
\end{tabular}

The COD removal efficiency decreased with increasing electrode spacing in the VSFCW-MFCs (Table 2). In addition, the electrical current does not enhance COD removal but the COD removal results in an electrical current [30]. However, varying the position of the anodic compartment did not affect DO.

In this study, the 20-cm electrode spacing achieved the maximum COD removal efficiency of $94.90 \%$, which resulted in a higher energy output with a power density of $0.0045 \mathrm{~W} / \mathrm{m}^{2}$ $\left(\mathrm{Pt}=0.025 \mathrm{~W} / \mathrm{m}^{3}\right)$ and fairly low coulombic efficiency of $0.31 \%$. This might be because acetoclastic methanogens compete with exoelectrogens for the same electron donor (acetate) and consume excess biodegradable carbon [31-33]. In addition, electron acceptors such as nitrate, sulfate, and oxygen may have caused the low efficiency.

\subsection{Effect of Influent COD on Bioelectricity Generation}

The COD concentration in influent affects the performance of the VSFCW-MFC reactor. The COD concentration should satisfy the microorganisms' requirements so that sufficient numbers of electrons are released for electricity production in the system.

The COD removal with the 20-cm electrode spacing at different influent COD concentrations is shown in Figure 5. With concentrations of 800, 400, and $200 \mathrm{mg} / \mathrm{L}$, the average COD removal efficiencies reached $90.76 \%, 90.99 \%$, and $90.45 \%$, respectively. 


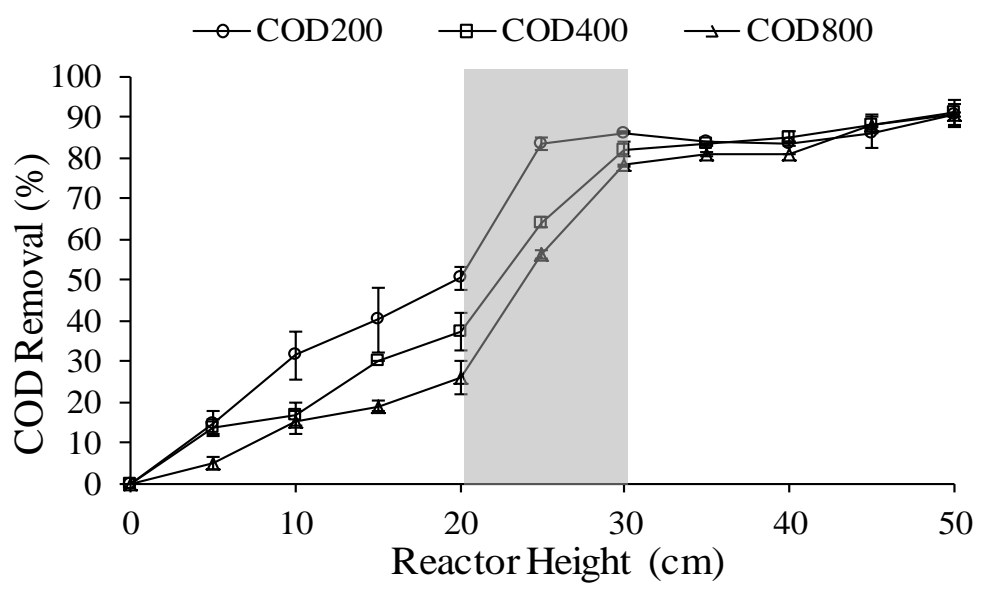

Figure 5. COD removal along the VSFCW-MFC with a 20-cm electrode spacing at different influent COD concentrations (mean $\pm \mathrm{SE}, n=4$ ). PBS and glucose were added to make SW with CODs of 200, 400 , and $800 \mathrm{mg} / \mathrm{L}$ with organic loadings of $0.30,0.71$, and $1.38 \mathrm{~kg} \mathrm{COD} /\left(\mathrm{m}^{3} \cdot \mathrm{d}\right)$, respectively. The gray area represents the projected anode area.

The maximum power densities and coulombic efficiencies for different influent COD concentrations are illustrated in Table 3. When the concentration increased from 200 to $800 \mathrm{mg} / \mathrm{L}$, negative open circuit potentials of the anode varying from -500 to $-526 \mathrm{mV}$ (vs. SCE) were observed. These results suggest that a higher COD concentration was beneficial for enhancing the active catalysis of exoelectrogens. This was because microorganisms consumed more oxygen to degrade the increased organic matter or SW with complex compounds with negative potential, and thus caused the open circuit potential to decrease. The anode potential varied from -0.25 to $0.21 \mathrm{~V}$, which increased the maximum current, suggesting that an anode potential in the range of -526 to $-500 \mathrm{mV}$ might enhance current generation [34]. The cathode open circuit potential simultaneously decreased from 241 to $101 \mathrm{mV}$ (vs. SCE). This marked decrease resulted in a decrease in the open circuit voltage from 741 to $627 \mathrm{mV}$. Previous studies have reported no improvement in COD removal efficiency by increasing the COD concentration. However, the organic matter was consumed when the cathode was exposed to diverse Methanobacterium [35]. The oxidation-induced consumption of overflow organic matter from the upper cathode compartment decreased the cathode potential. While the anode potential also decreased, the cathode controlled the performance of the VSFCW-MFC [18]. Power generation was limited by the cathode, although the exoelectrogens also significantly affected the performance of the system [28]. In addition, the coulombic efficiency and the maximum power density indicated that electron transfer to the external circuit was affected by overabundant COD, and that increases in the COD concentration did not increase the power density of the system, while oxygen was utilized as an electron accepter for the degradation of overflow SW by bacteria, rather than reacting with the electrons from the cathode. Based on the polarization curve, the internal resistance varied with different influent COD concentrations (Ro, $200=339.80 \Omega$; Ro, $400=360.50 \Omega$; and Ro, $800=395.55 \Omega$ ). Despite the variation in electrolyte resistance, our results suggest that the accumulation of microorganisms feeding on higher COD concentrations can block electron conduction on the interface of the activated carbon acting as an electrode, which results in higher internal resistance. Therefore, COD is a key parameter in the VSFCW-MFC, and it is critical to control its optimal range in the influent to optimize power generation and the treatment of wastewater. 
Table 3. VSFCW-MFC energy extraction with different influent COD concentrations (mean \pm SE, $n=4$ ). PBS and glucose were added to make SW with CODs of 200, 400 , and $800 \mathrm{mg} / \mathrm{L}$ with organic loadings of $0.30,0.71$, and $1.38 \mathrm{~kg} \mathrm{COD} /\left(\mathrm{m}^{3} \cdot \mathrm{d}\right)$.

\begin{tabular}{|c|c|c|c|c|c|c|c|c|}
\hline $\begin{array}{c}\text { Substrate } \\
\text { Concentration }(\mathrm{mg} / \mathrm{L})\end{array}$ & $\begin{array}{l}\text { Bv (kg COD/ } \\
\left.\left(\mathrm{m}^{3} \cdot \mathrm{NAC} \cdot \mathrm{d}\right)\right)\end{array}$ & Eoc $(m V)$ & Eoc, an $(\mathrm{mV})$ & Eoc,cat $(\mathrm{mV})$ & $\operatorname{Pmax}\left(W / m^{3}\right)$ & $\begin{array}{c}\text { Current } \\
\text { Generation }(\mathrm{mA})\end{array}$ & $\begin{array}{c}\text { COD } \\
\text { Removal (\%) }\end{array}$ & $\begin{array}{c}\text { Coulombic } \\
\text { Efficiency (\%) }\end{array}$ \\
\hline Glucose COD = 200 & $296.88 \pm 26.45$ & $741 \pm 34$ & $-500 \pm 39$ & $241 \pm 28$ & $0.20 \pm 0.02$ & $0.49 \pm 0.04$ & $90.45 \pm 4.14$ & $1.30 \pm 0.23$ \\
\hline Glucose COD $=400$ & $706.05 \pm 38.62$ & $698 \pm 57$ & $-511 \pm 47$ & $187 \pm 24$ & $0.17 \pm 0.02$ & $0.45 \pm 0.03$ & $90.99 \pm 3.52$ & $0.50 \pm 0.04$ \\
\hline Glucose COD $=800$ & $1378.17 \pm 121.23$ & $627 \pm 48$ & $-526 \pm 61$ & $101 \pm 13$ & $0.13 \pm 0.01$ & $0.40 \pm 0.03$ & $90.76 \pm 3.34$ & $0.23 \pm 0.03$ \\
\hline
\end{tabular}

Notes: Bv is the COD loading of the anode working volume; Eoc represents the open circuit voltage; Eoc,an is the open circuit potential of the anode; Eoc,cat is the open circuit potential of

the cathode; Pmax is the maximum power density calculated at an external resistance of $400 \Omega$; and current density and coulombic efficiency are consistent with Pmax. 


\subsection{Electrical Performance with the Addition of PBS}

A VSFCW-MFC with an external resistor of $1000 \Omega$ was assembled to investigate the electrical performance with the addition of PBS. Based on the previous experiment, the electrode spacing and the influent COD concentration were controlled at $20 \mathrm{~cm}$ and $200 \mathrm{mg} / \mathrm{L}$, respectively. The experiment was separated into three periods. The systems were operated at stable conditions for about three weeks for each period.

As shown in Figure 6a, the system reached a stable current density of $0.261 \mathrm{~A} / \mathrm{m}^{3}$ with the addition of $50 \mathrm{mM}$ PBS. After dosing with PBS was stopped, the current density was maintained at about $0.187 \mathrm{~A} / \mathrm{m}^{3}$. Subsequently, the system was switched to $330 \mathrm{mg} / \mathrm{L}$ with the addition of sodium chloride, and the stable current density was approximately $0.204 \mathrm{~A} / \mathrm{m}^{3}$. Electrical conductivity was measured at $8.25,1.24$, and $2.38 \mathrm{mS} / \mathrm{cm}$, in Periods 1,2 , and 3, respectively. The conductivity of adding $50 \mathrm{mM}$ PBS was almost seven-fold that of the system with no PBS. Due to the increased conductivity accelerating the transfer of protons in solution, the system current density increased accompanied by increased conductivity of the SW.

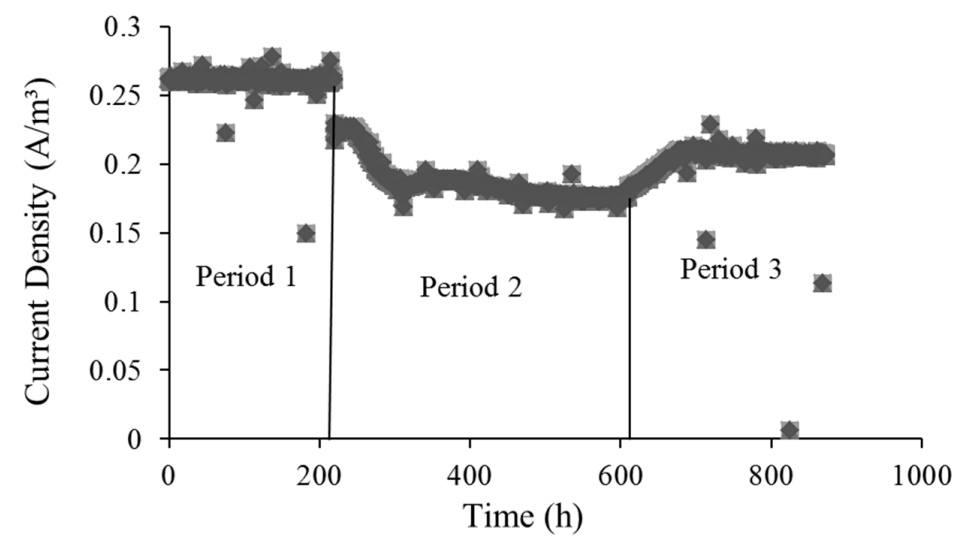

(a)

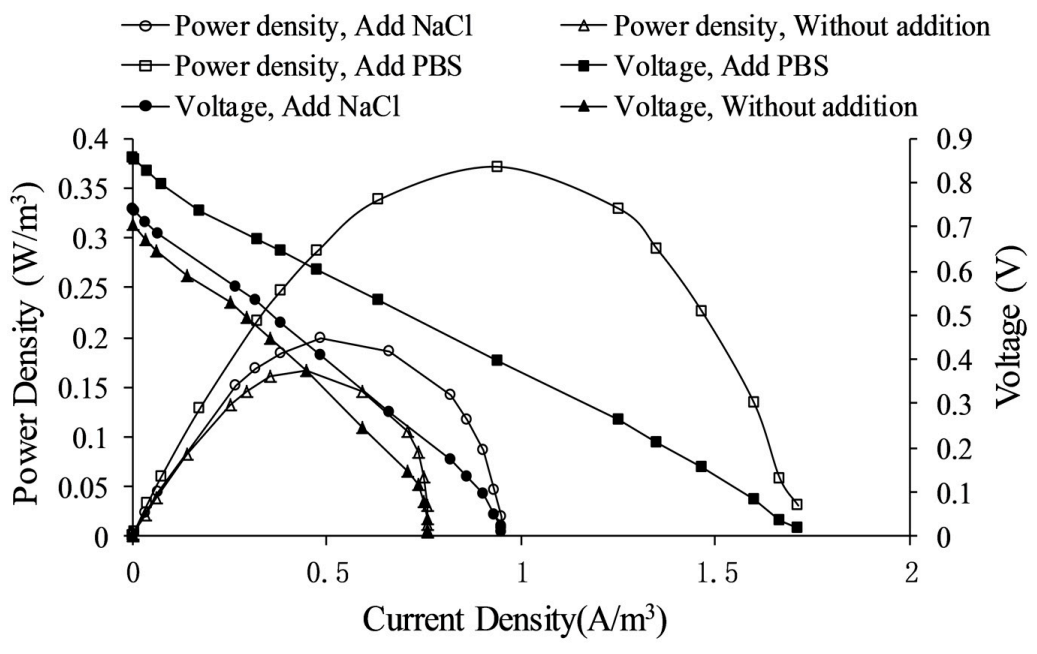

(b)

Figure 6. Electrical performance with the addition of PBS to the VSFCW-MFC (Period 1, SW was mixed with $50 \mathrm{mM}$ PBS to enhance the conductivity and buffer capability; Period 2, only SW was fed into the system; Period 3, sodium chloride was added to improve the conductivity of the SW). (a) Evolution of voltage against time. (b) Polarization curves and power density-current density curves. 
The polarization curves and the power densities for the different periods are shown in Figure $6 \mathrm{~b}$. The open circuit voltage reached 856, 706, and $741 \mathrm{mV}$ for Periods 1,2 , and 3, respectively. The maximum power density was $0.37(\mathrm{Pt}=0.063), 0.17(\mathrm{Pt}=0.029)$, and $0.20 \mathrm{~W} / \mathrm{m}^{3}\left(\mathrm{Pt}=0.034 \mathrm{~W} / \mathrm{m}^{3}\right)$, and the current density was approximately $0.94,0.45$, and $0.49 \mathrm{~A} / \mathrm{m}^{3}$, respectively. As already mentioned, the internal resistances were 209.78, 397.23, and $339.80 \Omega$ during the three periods. The wastewater had the maximum conductivity and minimum internal resistance when PBS was added. Hence, electricity generation was enhanced by increasing the conductivity and buffer capability.

Ohmic resistance is related to wastewater conductivity and electrode conductivity [17]. Zhu et al. showed that typical domestic wastewater and industrial effluent have a conductivity of $1 \mathrm{mS} / \mathrm{cm}$, while the electric conductivity was lower in a vertical subsurface flow constructed wetland [7]. Because the internal ohmic losses of our system were high, increasing the solution conductivity to reduce the internal resistance of the artificial wetlands was beneficial. Compared to the original wastewater, the maximum current density increased by $48.90 \%$ with the addition of sodium chloride. Due to the limitation of anode proton transfer, which constrained electricity production, $50 \mathrm{mM}$ PBS was added to regulate the biofilm $\mathrm{pH}$ and increase the conductivity, and a 2.1-fold increase in the current density was obtained relative to the current density in Period 1 . Torres et al. showed that current was linearly proportional to the concentration of the buffer solution at a constant potential [16]. The accurate injection of different concentrations of buffer solution to control the anode biofilm $\mathrm{pH}$ could be investigated in future studies.

\section{Conclusions}

In this study, the maximum current density, coulombic efficiency, and COD removal rate were obtained with an electrode spacing of $20 \mathrm{~cm}$. The variation in DO between the anode and cathode for different electrode spacings was significantly negatively correlated with the difference in voltage. A comparatively low COD concentration $(200 \mathrm{mg} / \mathrm{L})$ helped to enhance electricity generation. Furthermore, $50 \mathrm{mM}$ PBS added to the SW decreased the internal resistance and ohmic loss. To increase the use of CW-MFCs, optimum electrode materials for enhancing catalytic activities and electron transfer properties should be investigated in future studies.

Acknowledgments: This work was supported by the National Natural Science Foundation of China (Grant No. 41571476), National Key Technologies R\&D Program of China (Grant No. 2015BAL02B01-02), Provincial Key Technologies R\&D Program of Jiangsu, China (BE2015358) and Scientific Research Foundation of Graduate School of Southeast University (Grant No. YBJJ1647).

Author Contributions: The manuscript was written by Hailiang Song and Shuai Zhang but all the authors contributed to its preparation and review. Experiments were performed by Wenli Xiang. Data analyses were carried out by Xizi Long and Xiaoli Yang in discussion with Hua Li.

Conflicts of Interest: The authors declare no conflict of interest.

\section{References}

1. Liu, H.; Cheng, S.; Huang, L.; Logan, B.E. Scale-up of membrane-free single-chamber microbial fuel cells. J. Power Sources 2008, 179, 274-279. [CrossRef]

2. Leiva, E.; Leiva-Aravena, E.; Vargas, I. Acid Water Neutralization Using Microbial Fuel Cells: An Alternative for Acid Mine Drainage Treatment. Water 2016, 8, 536. [CrossRef]

3. Lu, Y.; Qin, M.; Yuan, H.; Abu-Reesh, I.; He, Z. When Bioelectrochemical Systems Meet Forward Osmosis: Accomplishing Wastewater Treatment and Reuse through Synergy. Water 2014, 7, 38-50. [CrossRef]

4. Kimura, Z.-I.; Okabe, S. Acetate oxidation by syntrophic association between Geobacter sulfurreducens and a hydrogen-utilizing exoelectrogen. ISME 2013, 7, 1472-1482. [CrossRef] [PubMed]

5. Logan, B.E. Exoelectrogenic bacteria that power microbial fuel cells. Nat. Rev. Microbiol. 2009, 7, 375-381. [CrossRef] [PubMed]

6. Hamelers, H.V.; Heijne, A.T.; Sleutels, T.H.; Jeremiasse, A.W.; Strik, D.P.; Buisman, C.J. New applications and performance of bioelectrochemical systems. Appl. Environ. Microbiol. 2010, 85, 1673-1685. 
7. Zhu, X.; Yates, M.D.; Hatzell, M.C.; Ananda Rao, H.; Saikaly, P.E.; Logan, B.E. Microbial community composition is unaffected by anode potential. Environ. Sci. Technol. 2014, 48, 1352-1358. [CrossRef] [PubMed]

8. Schrott, G.D.; Bonanni, P.S.; Robuschi, L.; Esteve-Nuñez, A.; Busalmen, J.P. Electrochemical insight into the mechanism of electron transport in biofilms of Geobacter sulfurreducens. Electrochem. Acta 2011, 56, 10791-10795. [CrossRef]

9. Zhang, X.; Shi, J.; Liang, P.; Wei, J.; Huang, X.; Zhang, C.; Logan, B.E. Power generation by packed-bed air-cathode microbial fuel cells. Bioresour. Technol. 2013, 142, 109-114. [CrossRef] [PubMed]

10. Liu, H.; Logan, B.E. Electricity generation using an air-cathode single chamber microbial fuel cell in the presence and absence of a proton exchange membrane. Environ. Sci. Technol. 2004, 38, 4040-4046. [CrossRef] [PubMed]

11. Fernández, F.; Lobato, J.; Villasenor, J.; Rodrigo, M.; Canizares, P. Microbial Fuel Cell: The Definitive Technological Approach for Valorizing Organic Wastes. Environment, Energy and Climate Change I; Springer: Berlin, Germany, 2014; pp. 287-316.

12. Yadav, A.K.; Dash, P.; Mohanty, A.; Abbassi, R.; Mishra, B.K. Performance assessment of innovative constructed wetland-microbial fuel cell for electricity production and dye removal. Ecol. Eng. 2012, 47, 126-131. [CrossRef]

13. Timmers, R.A.; Rothballer, M.; Strik, D.; Engel, M.; Schulz, S.; Schloter, M.; Hartmann, A.; Hamelers, B.; Buisman, C. Microbial community structure elucidates performance of Glyceria maxima plant microbial fuel cell. Appl. Microbiol. Biotechnol. 2012, 94, 537-548. [CrossRef] [PubMed]

14. Strik, D.P.; Snel, J.F.; Buisman, C.J. Green electricity production with living plants and bacteria in a fuel cell. Int. J. Energ. Res. 2008, 32, 870-876. [CrossRef]

15. Chiranjeevi, P.; Chandra, R.; Mohan, S.V. Ecologically engineered submerged and emergent macrophyte based system: An integrated eco-electrogenic design for harnessing power with simultaneous wastewater treatment. Ecol. Eng. 2013, 51, 181-190. [CrossRef]

16. Torres, C.I.; Marcus, A.K.; Rittmann, B.E. Proton transport inside the biofilm limits electrical current generation by anode-respiring bacteria. Biotechnol. Bioeng. 2008, 100, 872-881. [CrossRef] [PubMed]

17. Rozendal, R.A.; Hamelers, H.V.; Rabaey, K.; Keller, J.; Buisman, C.J. Towards practical implementation of bioelectrochemical wastewater treatment. Trends Biotechnol. 2008, 26, 450-459. [CrossRef] [PubMed]

18. Villasenor, J.; Capilla, P.; Rodrigo, M.; Canizares, P.; Fernandez, F. Operation of a horizontal subsurface flow constructed wetland-microbial fuel cell treating wastewater under different organic loading rates. Water Res. 2013, 47, 6731-6738. [CrossRef] [PubMed]

19. Doherty, L.; Zhao, Y.; Zhao, X.; Wang, W. Nutrient and organics removal from swine slurry with simultaneous electricity generation in an alum sludge-based constructed wetland incorporating microbial fuel cell technology. Chem. Eng. J. 2015, 266, 74-81. [CrossRef]

20. Wang, J.; Song, X.; Wang, Y.; Abayneh, B.; Ding, Y.; Yan, D.; Bai, J. Microbial community structure of different electrode materials in constructed wetland incorporating microbial fuel cell. Bioresour. Technol. 2016, 221, 697-702. [CrossRef] [PubMed]

21. Fang, Z.; Song, H.L.; Cang, N.; Li, X.N. Performance of microbial fuel cell coupled constructed wetland system for decolorization of azo dye and bioelectricity generation. Bioresour. Technol. 2013, 144, 165-171. [CrossRef] [PubMed]

22. Zhang, J.; Zhang, E.; Scott, K.; Burgess, J.G. Enhanced electricity production by use of reconstituted artificial consortia of estuarine bacteria grown as biofilms. Environ. Sci. Technol. 2012, 46, 2984-2992. [CrossRef] [PubMed]

23. Uría, N.; Muñoz Berbel, X.; Sánchez, O.; Muñoz, F.X.; Mas, J. Transient storage of electrical charge in biofilms of Shewanella oneidensis MR-1 growing in a microbial fuel cell. Environ. Sci. Technol. 2011, 45, 10250-10256. [CrossRef] [PubMed]

24. Apha, A. WPCF, Standard Methods for the Examination of Water and Wastewater; American Public Health Association/American Water Works Association/Water Environment Federation: Washington, DC, USA, 1995.

25. Liu, S.T.; Song, H.L.; Wei, S.Z.; Liu, Q.J.; Li, X.N.; Qian, X.W. Effect of direct electrical stimulation on decolorization and degradation of azo dye reactive brilliant red $\mathrm{X}-3 \mathrm{~B}$ in biofilm-electrode reactors. Biochem. Eng. J. 2015, 93, 294-302. [CrossRef] 
26. Fang, Z.; Song, H.L.; Cang, N.; Li, X.N. Electricity production from Azo dye wastewater using a microbial fuel cell coupled constructed wetland operating under different operating conditions. Biosens. Bioelectron. 2015, 68, 135-141. [CrossRef] [PubMed]

27. Aldrovandi, A.; Marsili, E.; Stante, L.; Paganin, P.; Tabacchioni, S.; Giordano, A. Sustainable power production in a membrane-less and mediator-less synthetic wastewater microbial fuel cell. Bioresour. Technol. 2009, 100, 3252-3260. [CrossRef] [PubMed]

28. Fan, Y.; Sharbrough, E.; Liu, H. Quantification of the internal resistance distribution of microbial fuel cells. Environ. Sci. Technol. 2008, 42, 8101-8107. [CrossRef] [PubMed]

29. Fang, Z.; Cheng, S.C.; Cao, X.; Wang, H.; Li, X.N. Effects of electrode gap and wastewater condition on the performance of microbial fuel cell coupled constructed wetland. Environ Technol. 2016. [CrossRef] [PubMed]

30. Ringeisen, B.R.; Henderson, E.; Wu, P.K.; Pietron, J.; Ray, R.; Little, B.; Biffinger, J.C.; Jones-Meehan, J.M. High power density from a miniature microbial fuel cell using Shewanella oneidensis DSP10. Environ. Sci. Technol. 2006, 40, 2629-2634. [CrossRef] [PubMed]

31. Freguia, S.; Rabaey, K.; Yuan, Z.; Keller, J. Electron and carbon balances in microbial fuel cells reveal temporary bacterial storage behavior during electricity generation. Environ. Sci. Technol. 2007, 41, 2915-2921. [CrossRef] [PubMed]

32. Lee, H.S.; Parameswaran, P.; Kato-Marcus, A.; Torres, C.I.; Rittmann, B.E. Evaluation of energy-conversion efficiencies in microbial fuel cells (MFCs) utilizing fermentable and non-fermentable substrates. Water Res. 2008, 42, 1501-1510. [CrossRef] [PubMed]

33. Rago, L.; Guerrero, J.; Baeza, J.A.; Guisasola, A. 2-Bromoethanesulfonate degradation in bioelectrochemical systems. Bioelectrochemistry 2015, 105, 44-49. [CrossRef] [PubMed]

34. Taylor, B.; Gardner, T.; Kenway, S. Southeast Queensland recycled water aspects and soil impacts. In Proceedings of the AWA Queensland 2007 Regional Conference, Sunshine Coast, Australia, 9-11 November 2007.

35. Siegert, M.; Yates, M.D.; Spormann, A.M.; Logan, B.E. MethanobacteriumDominates Biocathodic Archaeal Communities in Methanogenic Microbial Electrolysis Cells. ACS Sustain. Chem. Eng. 2015, 3, 1668-1676. [CrossRef]

(c) 2017 by the authors. Licensee MDPI, Basel, Switzerland. This article is an open access article distributed under the terms and conditions of the Creative Commons Attribution (CC BY) license (http:/ / creativecommons.org/licenses/by/4.0/). 